\title{
The Mousterian Settlement in the Ciota Ciara Cave: The Oldest Evidence of Homo Neanderthalensis in Piedmont (Northern Italy)
}

\author{
M. Arzarello ${ }^{1}$, S. Daffara ${ }^{1}$, G. Berruti ${ }^{2}$, G. Berruto ${ }^{1}$, D. Berté ${ }^{3}$, \\ C. Berto ${ }^{1}$, F.M. Gambari ${ }^{4}$, C. Peretto ${ }^{1}$ \\ ${ }^{1}$ Dipartimento di Biologia ed Evoluzione, Università degli Studi di Ferrara, C.so Ercole I d'Este 32. 44121 Ferrara. \\ E-mail: marta.arzarello@unife.it \\ 2 Universidade de Tras-os- Montes e Alto Douro \& Instituto Politecnico de Tomar \\ ${ }^{3}$ Università "Sapienza di Roma", Dipartimento di Scienze della Terra \\ ${ }^{4}$ Soprintendenza per i Beni Archeologici dell'Emilia Romagna
}

KEY WORDS: Mousterian, Piedmont, lithic technology, paleo-environment, supply areas.

\section{Introduction}

The Ciota Ciara cave is located in the karst of the Monte Fenera (Borgosesia,VC), at $670 \mathrm{~m}$ a.s.l. (Fig. 1). It is a still active karstic cave developed on more than $80 \mathrm{~m}$ in the principal axe. The first investigations with a naturalistic intent were conducted in the Monte Fenera in the second half of the nineteenth century; but it was

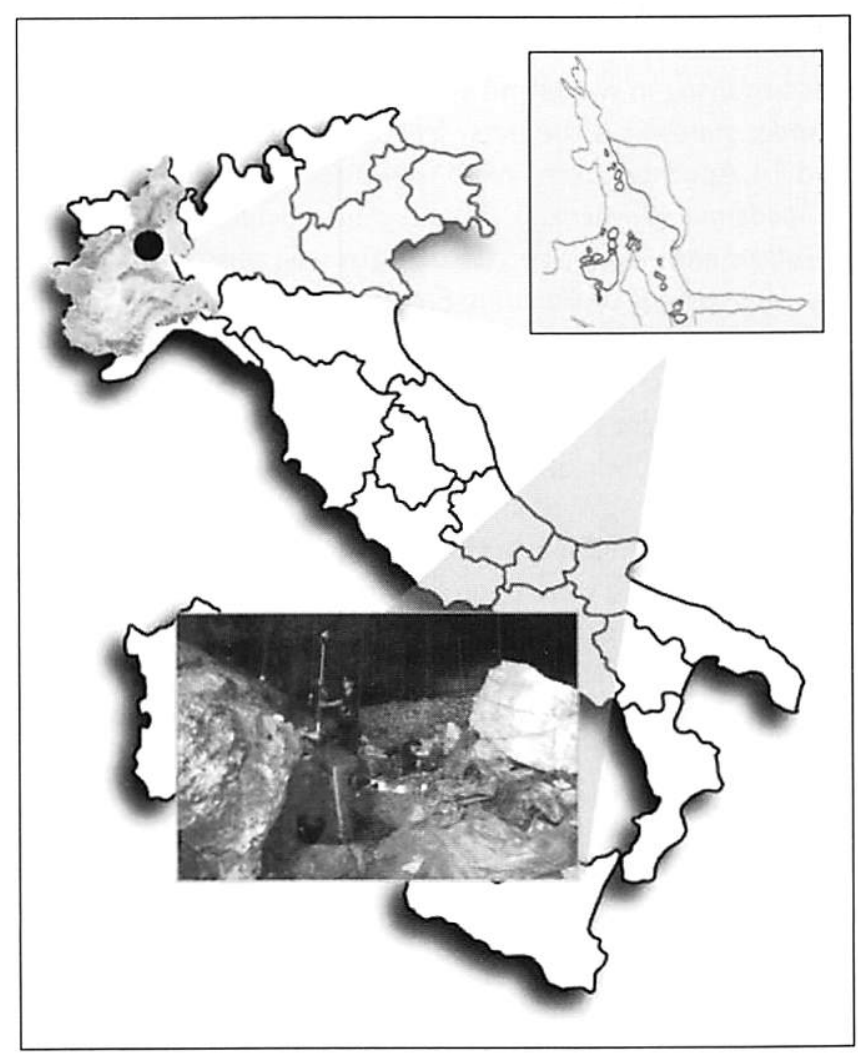

Fig.1. Ciota Ciara Cave position, cave map and excavation area. after the postwar period that research was started at the Ciota Ciara Cave. During more than 30 years several excavations were conducted by many researchers, including the Gruppo Archeologico Speloelogico di Borgosesia, C. Conti, C. Socin, G. Isetti, B. Chiarelli, F. Strobino and, above all, F. Fedele (Fedele, 1966; Fedele, 1984-85). At the end of the seventies the investigations at the Ciota Ciara were interrupted and started again in the nineties under the scientific direction of the Soprintendenza Archeologica del Piemonte, during 3 Years. In 2009 the systematic excavations at the Ciota Ciara were started again by the University of Ferrara in collaboration with the Soprintendenza Archeologica del Piemonte, under the direction of M.Arzarello. The new investigations are concentrated in the atrium of the cave (on $5 \mathrm{~m}^{2}$ during the firsts 2 years and enlarged to $8 \mathrm{~m}^{2}$ since 2011 thanks to the removal of a large fallen block) where 3 stratigraphic units were investigated: 13, 103 and 14. The 3 stratigraphic units have a horizontal disposition and are characterized by a reddish-brown clayey-sandy matrix with rare and altered centimeter-sized pebbles (more frequent in the S.U. 14 and very numerous in S.U. 103).

\section{Materials and Methods}

The lithic assemblage

The lithic assemblage (Fig. 2) of units 13,103 and 14 is composed by flakes, retouched tools, cores and debris (mainly made on quartz and rarely on flint, spongolite and jasper). Direct percussion by hard hammer is the only technique employed while the methods are various: S.S.D.A., discoid, Levallois and kombewa l.s. (Arzarello et al., 2011; Böeda, 1993, 1994). The lithic assemblage recovered from unit 13 is composed by 502 artefacts: 26 cores, 297 falkes and 179 debris. The S.S.D.A. exploitation is dominant. Most part of retouched blanks are sidescrapers (side or 


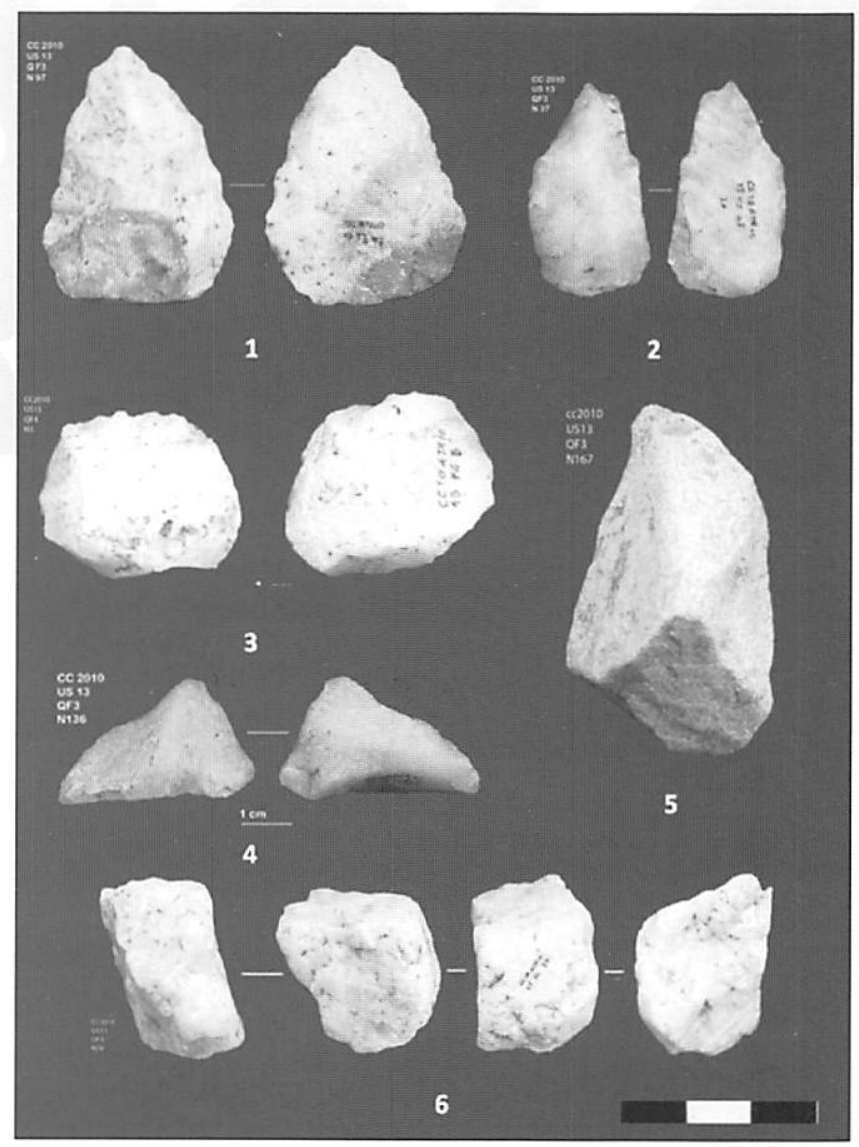

Fig. 2. Ciota Ciara litich industry: 1) convergent sidescraper on Levallois blank; 2) sidescraper on a discoid blank; 3) unifacial discoid core; 4) discoid flake; 5) S.S.D.A flake in spongolite; 6) S.S.D.A core.

convergent), followed by denticulate and notches. Flint débitage products are not abundant and only debris and a few unretouched S.S.D.A. flakes have been recovered. The Unit 103 has an extension of just $60 \mathrm{~cm}^{2}$ and within which only 17 S.S.D.A. unretouched flakes and some debris were found.

In the Unit 14, still under excavation, 778 artefacts, including 21 cores and 264 debris and 493 flakes, were found. The most employed raw material is once again quartz even if flint is here far more abundant. Two small jasper flakes and one opal side scraper have been recovered as well. The represented methods are the same described for US 13. Like in Unit 13, among the tools the scrapers (side, convergent and double) are the most abundant followed by notches.

\section{The supply areas}

The characterization of exploited raw materials (from Units 13,103, and partially US 14) was made by stereomicroscopic observations and, when necessary, by the use of a scanning electron microscope.

Many litologies are represented, in different proportion: quartz is the prevalent used material $(83,18 \%)$, followed by spongolite $(15,89 \%)$, sandstone $(0,56 \%)$, milonite $(0,19 \%)$ and opal $(0,19 \%)$.

The archeological record is constituted by many

typologies of quartz: macrocrystalline pegmatitic quartz, microcrystalline pegmatitic quartz and hyaline quartz.All these types of raw materials have been founded around the archaeological site. The quartz is localized at the base of the mountain, where it constitutes hydrothermal veins in permian volcanic rocks and in ercinic metamorphic rocks. The utilized spongolite is present in different qualities: more or less silicified and porous. This material is localized in the higher part of the mount in the formation of spongolithic limestone, with vertical variation in lithological characteristic, related to CCD variation during the deposition. Moreover we found sandstone, milonite and opal in the same area but only in secondary position.

\section{The usewear analysis}

The usewear analysis of quartz's artifacts was carried out using the low power approach (Semenov, 1954). The low-magnification analysis was performed by using a stereo microscope Seben Incognita 3 (10-80x) and a digital microscope Dinolight Am413T (5-230x). The high magnification analysis (on the experimental collection and on the flint's artifacts) was made using a metallographic microscope AmScope ME300T-M (40-640x) equipped with a AmScope MD600 camera.

The state of preservation of the lithic assemblage is very good and no chemical (white patina, bright spots) or mechanical (soil sheen, trampling) post-depositional alterations are evident. 130 artifacts (124 on local quartz and 6 on flint) were analyzed: 13 of them ( 4 tools and 9 unretouched flakes on quartz) have shown usewear.

\section{The faunal remains: the small mammals}

The small mammals from Units 13,103 and 14 (Fig. 3) are listed in Tab. 1.

Species living in woodland environments are dominant: Myodes glareolus is the most frequent rodent in Units 13 and 14.Another taxon linked to woodland environment is Apodemus (Sylvaemus); this subgenus includes A. (S.) sylvaticus and A. (S.) flavicollis that are well represented. Glis glis, Muscardinus avellanarius, Erinaceus europaeus and Sciurus vulgaris are present with few individuals.

Among Eulipotyphla (insectivores) Talpa caeca and Eriraceus europaeus are also markers of woodland environments (Amori et al., 2008a,b), while Talpa europaea, present with one individual in US 13, lives in many habitats (Amori et al., 2008d). Although less frequent in the assemblage, species typical of open grassland have been identified: Microtus arvalis and Microtus (Terricola) multiplex-subterraneus (Amori et al., 2008c;Aulagnier et al., 2008). One individual of Chionomys nivalis, a species which inhabits rocky environments, has been found in US 14.

The remains of Pliomys coronensis (= P. lenki; priority discussed by Terzea, 1983) are helpful for some chronological considerations. In Italy Pliomys coronensis is present from Middle Pleistocene (Isernia la Pineta, Sala, 1996; Boscochiesanuova, Bartololomei and Pasa, 1970; Visogliano shelter, Dalla Valle, 2011) to the beginning of Late Pleistocene (MIS 5, Ponte di Veia cave A lower levels, Bartolomei and Broglio, 1975). 
The Mousterian Settlement in the Ciota Ciara Cave:The Oldest Evidence of Homo Neanderthalensis in Piedmont

\begin{tabular}{|c|c|c|c|c|c|}
\hline & US 13 & $\%$ & US 14 & $\%$ & US 103 \\
\hline Arvicola amphibius & 2 & 4,08 & 2 & 4,26 & \\
\hline Myodes glareolus & 17 & 34,69 & 17 & 36,17 & \\
\hline Chionomys nivalis & & & 1 & 2,13 & \\
\hline Microtus arvalis & 5 & 10,20 & 4 & 8,51 & \\
\hline Microtus sp. & 2 & 4,08 & & & \\
\hline Microtus (Terricola) multiplex-subterraneus & 3 & 6,12 & 5 & 10,64 & \\
\hline Pliomys sp. & 1 & 2,04 & . & 0,00 & \\
\hline Pliomys coronensis & 2 & 4,08 & 2 & 4,26 & 2 \\
\hline Apodemus sp. & 2 & 4,08 & 2 & 4,26 & \\
\hline Apodemus (Sylvaemus) & 6 & 12,24 & 6 & 12,77 & \\
\hline Muscardinus avellinarius & 2 & 4,08 & & & \\
\hline Glis glis & 1 & 2,04 & 1 & 2,13 & \\
\hline Sciurus vulgaris & 1 & 2,04 & & & \\
\hline Talpa sp. & 2 & 4,08 & 1 & 2,13 & \\
\hline Talpa caeca & 2 & 4,08 & 5 & 10,64 & \\
\hline Talpa europaea & 1 & 2,04 & & & \\
\hline Erinaceus europaeus & & & 1 & 2,13 & \\
\hline Total Number of Individuals & 49 & & 47 & & 2 \\
\hline
\end{tabular}

Tab. 1. Ciota Ciara Cave: faunal list of small mammals form units 13,103 and 14.

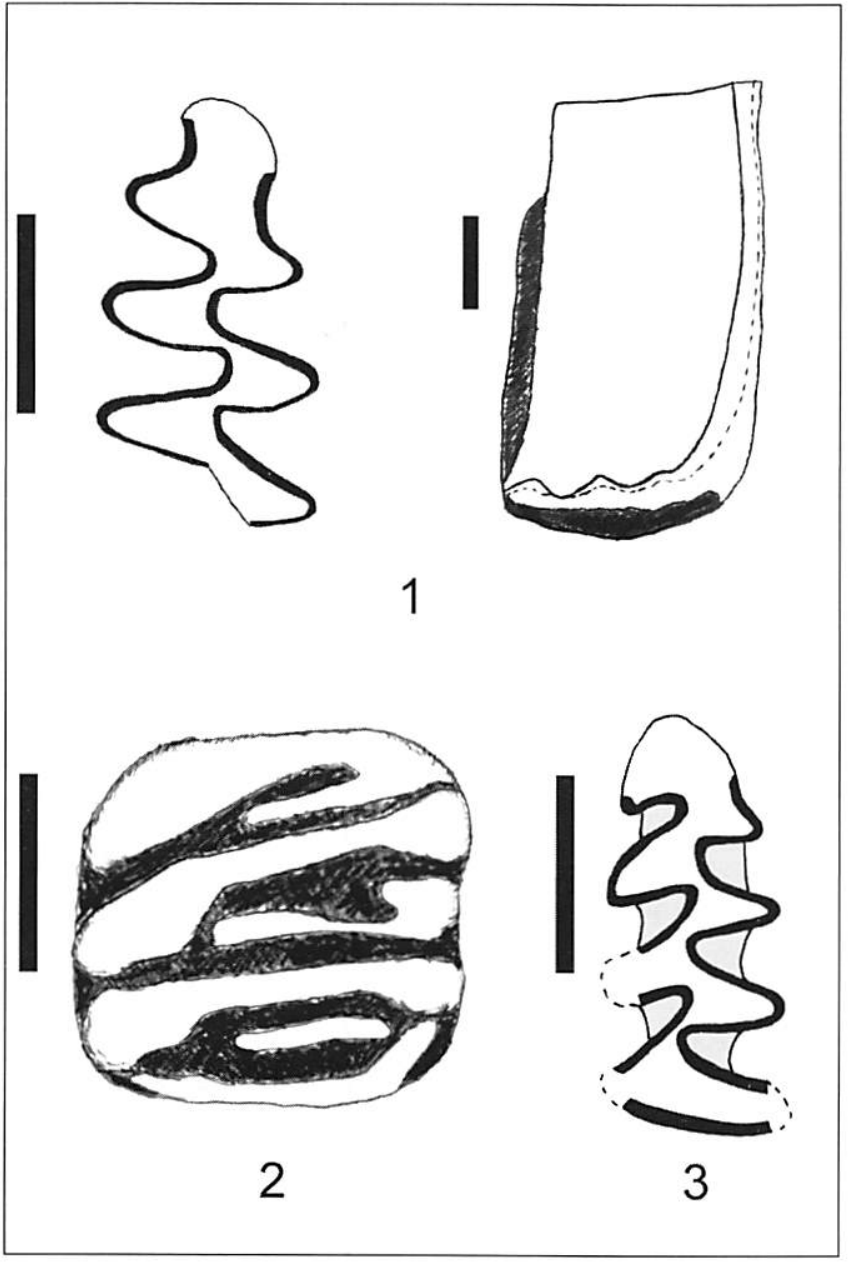

Fig. 3. Small mammals from Ciota Ciara cave: 1, Pliomys coronensis, first lower molar from US 14 (occlusal view and linea sinuosa); 2, Glis glis, first upper molar from US 14, occlusal view; 3, Myodes glareolus, first lower molar from US 13, occlusal view.
The macro fauna

829 remains was found and analyzed from US 13 (Tab. 2); 226 of them are not determinable (32\%). The macro fauna is composed by: Ursus spelaeus, Ursus arctos, Canis lupus, Vulpes vulpes, Meles meles, Lynx lynx, Rupicapra rupicapra, Cervus elaphus, Bos sp., Bos vel Bison and Hystrix sp. The genus Ursus is the most abundant taxon found in the Level 13 (60\% of the determinable remains). The genus is represented by two species: $U$. spelaeus and $U$. arctos. In the US 103, 98 remains were found (Tab. 2): 30 of them are not determinable (31\%). The genus Ursus is the most abundant and is represented by the same species found in the Level13.

\begin{tabular}{|l|l|r|r|}
\hline US & \multicolumn{1}{|c|}{ Species } & NR & NMI \\
\hline 13 & Ursus spelaeus & 215 & 9 \\
\hline 13 & Ursus cf. spelaeus & 15 & 1 \\
\hline 13 & Ursus arctos & 18 & 2 \\
\hline 13 & Ursus cf. arctos & 6 & 2 \\
\hline 13 & Ursus sp. & 246 & - \\
\hline 13 & Canis lupus & 6 & 1 \\
\hline 13 & Vulpes vulpes & 2 & 2 \\
\hline 13 & Meles meles & 6 & 1 \\
\hline 13 & Lynx lynx & 1 & 1 \\
\hline 13 & Carnivora & 24 & - \\
\hline 13 & Cervus elaphus & 8 & 2 \\
\hline 13 & Rupicapra rupicapra & 9 & 2 \\
\hline 13 & Bos sp. & 1 & 1 \\
\hline 13 & Bos vel Bison & 1 & 1 \\
\hline
\end{tabular}




\begin{tabular}{|l|l|r|r|}
\hline 13 & Hystrix sp. & 3 & 1 \\
\hline 13 & indet & 266 & - \\
\hline & Total & 829 & \\
\hline 103 & Ursus spelaeus & 26 & 5 \\
\hline 103 & Ursus ff. spelaeus & 2 & 1 \\
\hline 103 & Ursus arctos & 5 & 1 \\
\hline 103 & Ursus ff. arctos & 5 & 1 \\
\hline 103 & Ursus sp. & 22 & - \\
\hline 103 & Panthera leo & 1 & 1 \\
\hline 103 & Rupicapra rupicapra & 3 & 1 \\
\hline 103 & indet & 30 & - \\
\hline & Total & 98 & \\
\hline
\end{tabular}

Tab. 2. Ciota Ciara Cave: faunal list of lorge mommals form units 13 and 103.

\section{Results}

\section{Supply areas, reduction sequences and flakes'utilization}

The Middle Palaeolithic Human groups form the Ciota Ciara cave have collected the raw materials at a maximum of $5 \mathrm{Km}$ from the site.

The comparison between techno-typological and supply areas data do not provide evidence for any differential management of raw material in relation with débitage methods. Moreover quartz is the dominant lithology in the archaeological record, notwithstanding its worst débitage aptitudes and its bigger distance from the Ciota Ciara cave. This could be due to the fact that the spongolite is frequently very fractured and consequently unlikely utilizable.

The reduction sequences on quartz are complete even though no refitting was found because of the characteristics of this raw material. The best blocks, in terms of homogeneity, were exploited for Levallois débitage that is present in the lineal and centripetal modalities (Boëda, 1994). The blanks generally have medium dimensions (between 2 and $5 \mathrm{~cm}$ ) and in some cases are transformed in simples sidescrapers or convergent sidescrapers. The discoid method is principally unifacial considering the morphology of the blocks of quartz and the blanks (triangular and quadrangular thick flakes, often debordant) have, also in this case, medium dimensions. The most used method is the opportunistic one (c.f. S.S.D.A., Forestier, 1993) that is utilized for exploitation of all kind of blocs. The produced blanks have different morphologies and dimensions but are always characterized by at least one cutting edge. Some of them are transformed on sidescrapers, notches and denticulate. The opportunistic reduction sequences are usually short and never finalized to the total exploitation of raw material blocs. This behavior is probably related to the abundance of quartz near the site and to the minimum researched size of the flakes. The reduction sequence is not complete for the other raw materials. The flint's blanks derive just from an opportunistic débitage and, also if more numerous in Level 14 , are rare.

The débitage products are small or medium size $(1-4 \mathrm{~cm})$ and have different morphologies.

The usewear analysis shows the predominance of the processing of medium-hard and medium-soft materials. According to Odell (1981) this hardness is related to soft wood, hard wood, leather and deer antler. The probable impact fracture on a bi-convex convergent scraper and the presence of two artifacts with traces attributable to soft and medium-soft material working could be related to a small activity on carcass. The usewear analysis shows the predominance of the processing of secondary products, not related to the direct achievement of food resources.

\section{The paleo-environmental reconstruction}

The constant presence of the cave bear allows us to report our levels to a glacial period: this kind of bear, in fact, reached its maximum development and widest distribution during the last great glaciations ( $18-20.000$ years ago). The presence of some faunal elements like Cervus elaphus, Lynx lynx and Meles meles are indicative of the presence of a deciduous wood and a temperate-humid climate. Hystrix is indicative of a warm climate, currently lives in woodland savanna and in forest formation.

The small mammals association from Ciota Ciara cave gives some information about the environment that surrounded the site and allows to attempt a dating of the site.

The area around the site was covered by a deciduous woodland with some glades, where species such as Microtus arvalis and Microtus (Terricola) multiplex-subterraneus were prayed by owls. The presence of rocky areas, presumably from the occurrence of snow voles, is confirmed among large mammals by the chamois (NISP=9). The presence of warmer indicators (i.e. Erinaceus europaeus and Hystrix sp.) together with mammals that live in closed environments and the occurrence of Pliomys coronensis allow a calibration of the site into a temperate period of MIS 5 (MIS $5 c$ or $5 \mathrm{a}$ ), although no radiometric dating is available yet.

\section{Discussion}

The Monte Fenera is the only evidence of a prehistoric occupation of the Piedmont. The Ciota Ciara Cave was occupied by Homo neanderthalesnsis (a right temporal squama and two premolars were found inside reworked sediments outside the cave; Villa and Giacobini, 2005) during the MIS 5 in a temperate-humid period, as attested by the faunal remains. The environment was characterized by a deciduous woodland and, probably at the base of the Fenera mountain, by glades. The intersection between different habitats, the presence of lithic raw materials and water sources were the main factors that certainly favored the Human occupation during the Middle Palaeolithic. The characteristics of the lithic industries show an opportunistic behavior, also if all typical "Mousterian elements" are presents, in terms of supply areas and strategies of production. 
The technological characteristics of the lithic industries, the spatial distribution of the archeological materials together with the important presence of Ursus spelaeus, suggest that the cave was occupied repeatedly for short periods by Homo neanderthalensis during the Late Pleistocene.

\section{Acknowledgments}

Our work in the Ciota Ciara Cave have been possible tanks to the collaboration and support of the Fondazione Banca Intra ONLUS, the Borgosesia municipality and the Soprintendenza per i Beni Archeologici del Piemonte.

\section{References}

Amori, G., Hutterer R., Bertolino S., Mitsain G.,Yigit N., Kryštufek B., Muñoz L.J.P. 2008a. Talpa coeca. In: IUCN 2011. IUCN Red List of Threatened Species.Version 2011.2. <www.iucnredlist. org>.

Amori G., Hutterer R., Kryštufek B., Yigit, N., Mitsain G., Muñoz L.J.P. 2008b. Erinaceus europaeus. In: IUCN 2011. IUCN Red List of Threatened Species. Version 2011.2. <www.iucnredlist. org.

Amori G., Hutterer R., Kryštufek B., Yigit N., Mitsain G., Muñoz L.J.P. 2008c. Microtus arvalis. In: IUCN 2011. IUCN Red List of Threatened Species. Version 2011.2. <www.iuenredlist.org>.

Amori G., Hutterer R., Mitsain G., Yigit N., Kryštufek B., Muñoz L.J.P. 2008d. Talpa europaea. In: IUCN 2011. IUCN Red List of Threatened Species. Version 2011.2. <www.iucnredlist.org>.

Arzarello M., Peresani M., Fontana F. 2011. Manuale di tecnologia litica preistorica. Concetti, metodi e tecniche. Carrocci editore, Roma, 263 pp.

Aulagnier S.,Amori G., Hutterer R., Kryštufek B., Yigit N., Mitsain G., Muñoz L.J.P. 2008. Microtus multiplex. In: IUCN 2011.
IUCN Red List of Threatened Species. Version 2011.2. <www. iucnredlist.org>.

Bartolomei G., Broglio A. 1975. Risultati preliminari delle nuove ricerche nei depositi quaternari della Grotta di Veia. Boll. Mus. Civ. St. Nat. Verono, Il: 217-238.

Bartolomei G., Pasa A. 1970. La breccia ossifera di Boscochiesanuova nei Monti Lessini (Verona), depositi e la fauna. Memorie del Museo Civico di Storia Naturale di Verona, 17: 475-494.

Boëda E. 1993. Le débitage discoide et le débitage Levallois récurrent centripète. Bulletin de la Société Préhistorique Française, 90-6: 392-404.

Boëda E. 1994. Le concept Levallois: variabilité des méthodes. Paris, CNRS, monographie du CRA, 9:280 pp.

Dalla Valle C. 2011. I micromammiferi del Toringiono inferiore dei tagli dal 37 al 29 del Riparo di Visogliano (Duino Aurisina, Trieste). Master's Thesis. Ferrara University. Italy.

Fedele F. 1966. La stazione paleolitica del Monfenera (Borgosesia). Rivista di Studi Liguri,Anno XXXII: 5-105.

Fedele F. 1984-85. II Paleolitico in Piemonte: Le Alpi Occidentali. Ad Quintum Archeologia del Nord-Ovest, 7: 23-44.

Forestier H. 1993. Le Clactonien: Mise en application d'une nouvelle méthode de débitage s'inscrivant dans la variabilité des systèmes de production lithique du Paléolithique ancien. Poleo, 5: 53-82.

Odell G.H. 1981. The mechanism of use-breakage of stone tools: some testable hypothesis. J. Field Archaeol., 8:197-209.

Sala B. 1996. Gli animali del giacimento di Isernia la Pineta. In: C. Peretto (Ed.), I reperti paleontologici del giacimento paleolitico di Isernia La Pineta. Cosmo Jannone editore, Isernia: 25-49.

Semenov S.A. 1964. Prehistoric technology: an experimental study of the oldest Tools and Artefocts from traces of Manufacture and Wear, London, Cory, Adams \& Mackay, 211 pp.

Villa G., Giacobini G. 2005. I resti umani neandertaliani del Monte Fenera. D'ocqua e di pietra. II Monte Fenera e le sue collezioni museali,Associazione culturale ZEISCIU Centro Studi: 234 238. 